\title{
POLY-SYSTEMIC INTEGRITY OF THE PERSONALITY
}

\author{
Evheniia Geyko \\ Volodymyr Vynnychenko Central Ukrainian State Pedagogical University, Ukraine
}

\begin{abstract}
An attempt to reveal theoretical and analytical phenomenology of the personality integrity has been made in the article. The systemic approach determines the poly-systemic structure of the personality integrity. Applying the principle of systemacy to the reflection of psychological nature of the personality integrity, the components of the structure of integrity in interconnection and interdependence are considered. The specificity of the object and subject of the study, which influence the content of the personality integrity, is determined.
\end{abstract}

Keywords: systemic approach, poly-systemic integrity of the personality, integrity, personality integrity

Formulation of the problem. In the current context of reforming education in Ukraine, the problem of the development and formation of the personality integrity appears. However, the very concept of "personality integrity" needs clarification. Revelation of the psychological nature of this phenomenon makes it possible, in fact, systematic approach, which allows exposing the hierarchical complexity and interconnectedness of the structural components of this phenomenon.

Thus, the personality integrity is the unity of worldview orientations, which is manifested in the autonomy of the individual, responsibility for his actions, reflexivity, openness, ability for self-development and self-realization. The opposite of "integral personality" is "fragmentary personality" - personality, whose structural components conflict with each other and do not represent integral picture of the world.

Analysis of relevant scientific researches and publications. The systemic approach involves obligatory analysis of the system structure (psyche, personality). At the same time, it is special open feedback system. Thus, as noted by M. Savchin: "At each level of determination, it is included in the regulation of 
the subject interaction with broader biological system (at the level of the organism), the social system (at the level of the individual), created by cultural and historical values of the society and the physical world (at the level of the personality) and the spiritual sphere (at the level of the immateriality)" [7].

The further development of the systemic approach is considered to be integration of age, psychological and subjective. As noted by M. Yermolaieva, D. Lubovskyi, attempts of holistic description of human development along the life path are characterized by paradigmatic changes, namely: psychology of childhood is primarily represented in the theoretical views of L. Vyhotskyi, O. Leontiev, D. Elkonin, however, youth often appears with the historical and sociological study of the life path, developed in the works of I.Kohn, and maturity, aging - with the subjective approach of

S. Rubinstein, B. Ananiev [5].

Within this approach it is possible to consider the activity of the subject in terms of its own development. This allowed us to introduce into the psychological science the concepts of "self-development", "self-realization", and "selfdetermination", aimed at identifying the origins of human mental development. However, this approach is implemented in the adult learning process because it cannot be understood differently than self-development.

Thus, M. Yeromolaiev and D. Lubovskyi emphasize that the importance of combining two approaches within systemic one is due to the fact that it is impossible to fully disclose the development of adult in his/her integrity, the specificity of his/her self-development without representing driving forces, the mechanisms of this process, which go back to childhood [5, p. 105].

In other respects, it is worth noting that the integration or implementation of systemic-integral approach contributes to the representation of the psychological nature of the personality integrity. However, based on the interconnectedness of the elements, internal correlation and hierarchy of components or elements of the system, it is right to use the term "poly-system", and accordingly, it's worth considering strictly "poly-systemic integrity of the personality". Such perspective is insufficiently researched in modern psychological science.

Thus, the purpose of our article is to reveal features of the personality integrity as essential prerequisites for its self-realization from systemic approach 
point of view, which helps to identify the most essential features of this phenomenon, as well as to determine its poly-systemic structural organization.

Presenting main material. Embodying the concept of "the integrity" actually within systematic approach, S. Maksimenko considers integrity as meaningful (key) sign of the personality. Characterizing the personality as formation consisting of individual mental phenomena (processes, states, properties), the scientist insists that the personality is not the sum of these phenomena, is not "adding conceptions" of its individual components, simultaneously, integrity of the personality is not determined by the sum of its components. Even each component does not exist separately, independently. "It is the bearer of the whole personality, as well as his/her imprint. Personality lives, develops and formes only collectively, as integrity", as S. Maksimenko notes [6].

Afterwards, the researcher focuses on the "living movement of the integrity", that is, emphasizes the constant development, dynamics, and change of the integrity itself as a sign of personality. In this way, we can observe the interconnections of the integrity components, their alterations, and, consequently, the personality as a whole. However, the author notes that such changes are secondary and even tertiary compared to the whole - the personality. "They appear after separate live movement of the personality and contribute to subsequent integral movements". Such ability of the personality as integrity becomes apparent in the reflection of both at the level of the particular trait (component of the integrity) and at the level of the personality.

According to the principle of the personality integrity concept by S. Maksimenko, the personality must exist as a whole, and its own integrity is expression and essential feature of the personality. "Thus, the personality integrity specifically covers all structural and dynamic manifestations of human life. It is caused not by the sum of individual components, but by the integrated unity of three origins of the individual existence - biological, social and spiritual". However, the scientist notes that it is impossible to consider integrity as an attribute trait of the personality. Because such integrity is unique in each individual, something similar to others, but still, significantly different.

The problem of the psychological nature of integrity is closely linked to the personality immateriality. M. Savchin even introduces the concept of "integral 
vital activity" into psychology. Therefore, "according to the spiritual paradigm, the personality and mentality should be considered in the context of integral vital activity, the main content of which is its (human being) self-perfection as the image of God, directed toward the likeness of God, and the world perfection (creation of love, good) as the Kingdom of God on earth"[7].

The scientist also insists on considering the personality integrity in the context of leading principles of psychological science: "the subject integrity is the basis of systemic connections of all its psychic qualities, often contradictory, difficult-to-integrate, and above all, it means unity, integrity of its activity and development". Thinking over the personality nature, the scientist notes that "individual subject is defined on the basis of its unique contribution to the common, integral activity, participation in its design, construction and development". This is actually the principal criterion for self-development of individual subject, person who is at the highest level of activity, integrity (systemacy), autonomy. In addition, the author notes that the appointed level is individualized for each individual or group of people, taking into account motivation, abilities, intelligence, will, real historical conditions.

A person is not born a subject, but becomes it, separating him/herself from surroundings and opposing him/herself as an object of action, cognition, contemplation. In the course of activity, reality appears to the subject not only as system of irritants with which he interacts at the reaction level, but also as object, and other people - also as subjects.

Let us appeal to the concept of "the personality integrity" in the conception of the personality proposed by T. Tytarenko. The scientist, in particular, believes that introduction of the category "the life-world", ensures the true integrity of man and the world, makes it possible to study the psychological reality within which every human life develops [8].

Within his own conception of the personality, T. Titarenko distinguishes individual variants of the psychological spaciousness as well as the concept of "the personality integrity".

It is worth noting that the concept of "psychological spaciousness of the personality life-world" is characterized by the following properties: 
- the availability of poles - good and evil, positive and negative. There is constant interaction between these poles, that creates, depending on the advancement of the individual to the pole, personal potential, stimulating personal growth, or, conversely, neurotic protection, aggressive manifestations, frustrating reactions that cause panic, fear or shame.

Considering the principles of systemic-integral approach, it should be pointed out that the personality integrity (as a system) consists of many basic interrelated, interdependent elements. The problem of criteria for determining the basic elements, their specificity and peculiarities of manifestation is the most complex and hardly covered in scientific researches. The issue of complexation of the personality integrity with regard to its differentiation remains underdeveloped.

Considering this concept of the personality integrity, the personality and the world are simultaneously integral and independent systems. The personality component has biochemical, physiological, somatic properties. The world component has the same qualities, but when another person appears, the physical, mechanical, and other properties are added if things and objects appear as the world. The integrity is thus separated and its components discrete.

Systems are somewhat other than components, supercomposite, and extrasensory formations. The personality integrity (as a system) is the sphere of functions that overlaps the components of the individual and the world. The personality as a system differentiates itself from the personality as a component, crosses its physical limits and assimilates the world. In the personality (as a system), the individual plays the role of system-forming quality, and its world the role of controlled subsystem. In turn, the world (as a system) is the sphere of functions that overlaps the components of the world and the personality. The world as a system stands out from the world as a component, goes beyond its physical limits and engages the personality. In the world as a system, the role of the system-forming quality is fulfilled, and the personality - the role of the managed system.

The personality (as a system and the world) as a system is differentiated, but also interacts. One of the effects of their interaction is expansion. Personality enters the world and the personality system expands; the world enters the personality and the world system expands. The world ( as a subsystem of 
personality), and personality (as a subsystem of the world) are the results of extensions and interactions of the personality and the world.

In the concept of the personality integrity (as a system) the concept of interaction extends to the personality, world and activity. According to indicated concept, the integral world appears as poly-system and obeys the principle of the duality of qualitative certainty: the personality and the world interact as systems and subsystems of each other. It is important that several forms of activity give nature of active polyphony to the personality and the world interactions.

Thus, the integral world is organized into poly-system through the interaction of the personality and his/her world in two positions: independent systems and subsystems of each other. The poly-systemic interactions of the personality and his/her world are divided into different components. The interactions are localized in the field of the personality component and in the field of the world component. The position (system or subsystem), localization (in the component of the personality and the world) and interaction (taking into account position and localization) are the key parameters of integral world. They give it variety, diversity, relativity.

Depending on position, (localization and interaction) the four spheres of the integral world are distinquished. In the first sphere (in the field of the personality component) systemic quality of the individual is localized. This is the sphere of the "Personality" system. In it, the "Personality"as a system does not interact with the world as a system. In the second sphere (poly-component of the world) the systemic quality of the world is localized. This is the sphere of the "World" system. In it, the"World", as a system, interacts with the personality as a subsystem.

It is the systemic approach that draws attention to the personality integrity. In the cognitive model of the personality integrity, as a device for dynamic information processing, exclusively systemic issues are considered: integration, fragmentation, multidimensionality, hierarchy. At the same time, the cognitive paradigm exerts certain influence on the understanding of the personality integrity. However, consideration only from the point of view of the mechanism of information processing leads to the fact that the phenomenon of the personality integrity loses its own nature and specificity. Separation of subsystems in integrities (cognitive-affective-performing and interpersonal, cognitive, emotional) is logical for the Connectionist model. 
The personality integrity study in the unity of its differentiation and integration within systemic approach is important. It is the concept of the personality integrity that can serve as such a basis. Such concept makes it possible to systematically imagine the personality integrity as poly-system, to identify modalities, submodalities and dispositions as its various aspects.

From the position of systemic-integral approach, the personality integrity is defined in this way: the mental representation of the integral world to individual. Mental representations are diverse, interpersonal, positional; which are subject to change.

For determination of systemic-integral approach, the term "poly-systemic personality integrity" should be used, which is similar in meaning to the concept of "poly-modality", which was introduced by L. Dorfman [4]. Poli-modality is based on the principles of the personality "Self-concept", developed by J. Kihlstrom, L. Foster, S. Klein and refined by L. Dorfman in his concept of the meta-individual world. So, the "Self-concept" appears in the form of mental representation of the person's particularities of his/her meta-individual world.

However, the poly-system is characterized by the duality of qualitative certainty and relativity. The duality has manifestation: stability and variability, coherence and inconsistency, rationality and irrationality, ability to plan and automatism, initiativeness and rigidity.

In L. Dorfman's researches the general properties of poly-modality are defined, attention is focused on submodalities, along which systems, modalities and dispositions were considered [4, p. 96 - 157].

Conclusions and prospects for further researches. Thusly, the integrity is the proper interrelation of the elements, the internal correlation and correspondence, the hierarchy of components or elements of the system. The integrity is related to the hierarchy of structures. However, the hierarchy of structures is considered common feature of integrity. Also, each integrity component, in turn, has its own structure. The organization of integrity is the consentaneity of the structural formations of parts in general structure.

The integrity is determined by the totality of the system's internal and external relationships, connections and interactions. The internal and external connections of the integral system are in some way consistent (harmonized) with each other. During the formation and existence of integrity, there is always 
discrepancy between the external and internal connections of the system. Therefore, the integrity of the system is not so much the result of its previous development, but the ability to maintain such state in the process of constant movement, change and development. Thus, the integrity of the system is both prerequisite and result of itself.

Apart from this, of great importance is the fact that the integrity of the system is not only the correspondence of the elements, the integrals of a body, but also the connection of each element with the whole. The interaction of part, element, whole is characterized by interference. During the interaction of the part and the whole, when the part can represent the whole and the whole penetrates into the parts, this is the way of developing the part and the whole, improving the structure of the system as a whole and its individual components. The leading action in this complex process belongs to the structure of the whole; that is the whole that determines its own progress through the development of the parts.

As leading factors, it is advisable to identify systemic concepts of isomerism, multidimensionality, hierarchy. Isomerism is considered as a mechanism of communication, of transitions from one component of multimodal personality integrity to another. Multidimensionality should be revealed as multiaspectuality of the poly-systemic integrity of the personality. The hierarchy must be reflected through the "vertical" and "horizontal" in the structure of the multimodal personality integrity. So, the "vertical" structure is Holon, special form of correlation of the whole and parts.

Suchwise, the personality integrity is revealed through the agreed structural elements (systems, modalities, dispositions) in the general structure on the principle of poly-system. Poly-systemic personality integrity is the corresponding interconnectedness of elements, internal correlation and hierarchy of components or system elements.

The research prospect is to study the peculiarities of poly-systemic personality integrity formation in ontogeny from the position of systemic-integral approach.

\section{References:}


Ball, G. O. (1998). Problema obhruntuvannia suspilnoii ideolohiii u svitli humanistichnoho pidhodu [The problem of justification of social ideology in the light of a humanistic approach] / G. O. Ball // Psiholohopedahohichna nauka i suspilna ideolohiya: Materiali metodolohichnoho seminaru Akademii pedahohichnyh nauk Ukrainy, 12 lystopada 1998 r. [Psychological and Pedagogical Science and Social Ideology: Materials of the Methodological Seminar of the Academy of Pedagogical Sciences of Ukraine] Kyiv. Gnozis. S. 28 - 32. [in Ukrainian].

Bertalanfi, L.(1960). Obschaya teoriya sistem [General theory of systems] / L. fon Bertalanfi. Moscow. Mir. 328 s. [in Russian].

Vyhotskii, L. S. (2005). Psiholohiya razvitiia cheloveka [Psychology of human development] / L. S. Vyihotskii. Moscow. Smysl; Eksmo. 1136 s. [in Russian].

Dorfman, L. Ya. (2004). Ya-kontseptsiia: differentsiatsiia i intehratsiia [I-concept: differentiation and integration] / L. Ya. Dorfman. // Intehralnaia individualnost, Ya-kontseptsiia, lichnost [Integral personality, I-concept, personality] / Pod red. L. Ya. Dorfmana. Moscow. Smysl. S. 96 - 123. [in Russian].

Yermolaieva, M. V. (2012). Teoretyko-metodolohicheskii analiz razvitiia vnutrennei pozitsii lichnosti na protiazhenii zhiznennoho puti (integratsiia vozrastno-psihologicheskoho $i$ sub'ektnoho podhodov) [Theoretical and methodological analysis of the development of the internal position of the person throughout the life (integration of agepsychological and subjective approaches)] / M. V. Yermolaieva, D. V. Lubovskii // Mir psiholohii. 3 (71). S. 104 - 113. [in Russian].

Maksymenko, S. D. (2007) Struktura osobystosti [The structure of the person] // Prakt. psyholohiia ta sots. robota. № 1. S. 1 - 13. [in Ukrainian].

Savchin, M. (2011). Doslidzhennia osobystosti v konteksti duhovnoii paradigmy psyholohii [Investigation of personality in the context of the spiritual paradigm of psychology] // Psyholohiia osobystosti, No 1 (2). S. 191 199. [in Ukrainian].

Tytarenko, T. M. (2003). Zhyttievyi svit osobystosti: u mezhakh i za mezhamy budennosti [The vital world of personality: within and beyond the 
ordinary] / T. M. Tytarenko. Kyiv: DP Spetsializovane vydavnytstvo «Lybid». 376 s. [in Ukrainian] 